\title{
Evaluation of Four Bedside Test Systems for Card Performance, Handling and Safety
}

\author{
Felix Giebel $^{\mathrm{a}} \quad$ Susanne M. Picker ${ }^{\mathrm{b}} \quad$ Birgit S. Gathof ${ }^{\mathrm{b}}$ \\ a Department of Anesthesia, \\ b Transfusion Medicine, University of Cologne, Germany
}

\author{
Key Words \\ Blood transfusion - ABO compatibility testing . \\ Bedside test - Safety
}

\section{Summary}

Objective: Pretransfusion $A B O$ compatibility testing is a simple and required precaution against $A B O$-incompatible transfusion, which is one of the greatest threats in transfusion medicine. While distinct agglutination is most important for correct test interpretation, protection against infectious diseases and ease of handling are crucial for accurate test performance. Therefore, the aim of this study was to evaluate differences in test card design, handling, and user safety. Design: Four different bedside test cards with pre-applied antibodies were evaluated by 100 medical students using packed red blood cells of different $A B O$ blood groups. Criteria of evaluation were: agglutination, labelling, handling, and safety regarding possible user injuries. Criteria were rated subjectively according to German school notes ranging from $1=$ very good to $6=$ very bad/insufficient. Results: Overall, all cards received very good/good marks. The ABO blood group was identified correctly in all cases. Three cards (no. 1, no. 3, no. 4) received statistically significant $(p<0.008$ ) prominence (mean values shown) concerning clearness of agglutination (1.7-1.9 vs. 2.4 for no. 2). Systems with dried antibodies (no. 2, no. 4) outmatched the other systems with respect to overall test system performance (2.0 vs. 2.8-2.9), labelling (1.5 vs. $2.2-2.4$ ), handling (1.9-2.0 vs. 2.5 ), and user safety (2.5 vs. 3.4). Analysis of card self-explanation revealed no remarkable differences. Conclusion: Despite good performance of all card systems tested, the best results when including all criteria evaluated were obtained with card no. 4 (particularly concerning clear agglutination), followed by cards no. 2, no. 1, and no. 3 .

\author{
Schlüsselwörter \\ Bluttransfusion, AB0-Kompatibilitätstest · Bedside-Test . \\ Sicherheit
}

\section{Zusammenfassung}

Hintergrund: Der vor jeder Transfusion obligatorisch durchzuführende Bedside-Test zur Prüfung der AB0-Kompatibilität ist eine einfache Vorsichtsmaßnahme gegen die AB0-inkompatible Bluttransfusion, einem der größten Risiken der Transfusionsmedizin. Während eine eindeutige Agglutination der wichtigste Parameter für die korrekte Testinterpretation darstellt, sind Anwendersicherheit und eine einfache Handhabung entscheidend für die akkurate Testdurchführung. Design: 100 Medizinstudenten untersuchten Proben aus Erythrozytenkonzentraten unterschiedlicher Blutgruppen mit 4 verschiedenen BedsideTestkarten-Systemen. Evaluationskriterien waren: Agglutination, Kennzeichnung, Handhabung und Einschätzung der Verletzungsgefahr. Die einzelnen Kriterien wurden nach deutschen Schulnoten von $1=$ sehr gut bis $6=$ sehr schlecht/unzulänglich subjektiv bewertet. Ergebnisse: Alle Karten wurden gut bis sehr gut bewertet und führten zu einer korrekten Identifizierung der AB0-Blutgruppe. Drei Karten (Nr. 1, Nr. 3, Nr. 4) zeigten eine signifikant $(p<0,008)$ deutlichere Agglutination (1,7-1,9 vs. 2,4 für Nr. 2). Systeme mit auf die Karte aufgebrachten Antikörpern (Nr. 2, Nr. 4) bekamen bessere Noten für das Testsystem insgesamt $(2,0$ vs. $2,8-2,9)$, die Kennzeichnung $(1,5$ vs. $2,2-2,4)$, die Handhabung (1,9-2,0 vs. 2,5) und die Anwendersicherheit $(2,5$ vs. 3,4$)$ als solche mit Antikörpern in flüssiger Form. Die Beurteilung, ob das Kartendesign ausreichend selbsterklärend war, zeigte keine wesentlichen Unterschiede. Schlussfolgerung: Trotz guter Anwendbarkeit aller 4 Systeme gab es Unterschiede vor allem bei der Agglutination und der Anwendersicherheit. Die Zusammenfassung aller evaluierten Kriterien ergab rechnerisch Vorteile für Karte Nr. 4, in absteigender Reihenfolge gefolgt von Karte Nr. 2, Nr. 1 und Nr. 3.

\begin{tabular}{ll}
\hline KARGER & $\oplus$ 2008 S. Karger GmbH, Freiburg \\
Fax +497614520714 & Accessible online at: \\
$\begin{array}{l}\text { E-mail Information@Karger.de } \\
\text { www.karger.com }\end{array}$ & www.karger.com/tmh \\
&
\end{tabular}




\section{Introduction}

Non-infectious hazards such as incidents of erroneous ABO mismatches are now the main risks associated with blood transfusion [1]. The bedside performance of the ABO compatibility test is considered as the ultimate blood safety wall as ABO-incompatible blood transfusion can reliably be prevented [2-5]. Therefore, it is a legal requirement in many European countries $[3,4,6]$. Reluctant testing may result in inaccurate performance causing $\mathrm{ABO}$ mismatch [7-9] and the risk of lethal transfusion reactions [10-12]. Errors can be due to device failures, poor technique, and incorrect interpretation. Among 161 retrospectively evaluable cases of ABO mismatch reported in a French hemovigilance study between 1991 and 1998 [13], the mandatory bedside test was not performed at all in one third of cases. In a further third of cases, problems of location (test not done at the bedside), time (test done some time before/after the transfusion) or identity (incorrect blood transfused) were detected. The final third of errors was related to incorrect techniques resulting in incorrect interpretation. Additionally, if bedside testing had been performed correctly in each case, 7 of 8 ABO-incompatible transfusions diagnosed at the Charité University Hospital in Berlin, Germany, between January 1997 and December 2004 would have been prevented [14]. As a consequence this test needs, apart from valid results, easy conduction and design to ensure accurate performance and correct use being crucially important for correct test interpretation $[15,16]$. Despite this, comparative data of different bedside techniques due to different card designs (e.g. dried antibodies vs. liquid antibodies $[17,18]$ ), is scarce $[8,19]$.
While some investigators evaluated the influence of user experience and training on test reliability [20,21], no studies have yet been published that investigate the impact of card design on performance and interpretation facility. In this study, four different bedside test systems with widespread use in the European community were evaluated by hardly experienced users with respect to agglutination/interpretation, ease of handling, and user convenience.

\section{Material and Methods}

All commercially available bedside compatibility test systems with pre-applied antibodies (bedside cards) used in this study are specified in table 1. Dried colored antibodies were mounted on the surface of cards no. 2 and no. 4 and had to be dissolved with a suspension of saline and red blood cells of the blood to be tested (card type I). Cards no. 1 and no. 3 contained antibody solutions in small pits covered by a plastic film where the blood sample had to be injected through before testing (card type II). Test systems were evaluated by 100 medical students in the beginning of their clinical training. All students were provided with general working instructions on a working sheet, specific instructions on the cards or their wrappings (except for card no. 3 offering one instruction per 20 cards only), evaluation sheets, syringes, cannulas, and mixing-sticks. During the first $15 \mathrm{~min}$, the students were informed about bedside testing and the study's aim. They were then invited to familiarize themselves with the devices and ask questions concerning the overall performance. Each student was then given a questionnaire and a blood sample prior harvested from packed red blood cells by the investigator. Points of questionnaire were: distinct/clear agglutination, self explanation of the system examined, unambiguous labelling, ease of handling, simplicity of use of the overall test system, and user safety. Results were rated subjectively using German school notes $(1=$ very good, $2=\operatorname{good}, 3=$ satisfactory, $4=$ sufficient, $5=$ unsatisfactory, 6 = very bad/insufficient).

Table 1. Technical properties and costs of the bedside test systems examined

\begin{tabular}{|c|c|c|c|c|}
\hline & \multicolumn{4}{|l|}{ Card number } \\
\hline & no. 1 & no. 2 & no. 3 & no. 4 \\
\hline Designation & ABO-trol ${ }^{\circledR}$ forte II & Eldon $^{\circledR} 2511$ & Medtrokarte ${ }^{\circledR}$ NK4 & Serafol $^{\circledR} \mathrm{ABO}+\mathrm{D}$ \\
\hline Company & $\begin{array}{l}\text { Organon Teknika, } \\
\text { Eppelheim, Germany }\end{array}$ & $\begin{array}{l}\text { Eldoncard A/S, Gentofte, } \\
\text { Denmark }\end{array}$ & $\begin{array}{l}\text { Medtro GmbH, } \\
\text { Leimen-Gau, Germany }\end{array}$ & $\begin{array}{l}\text { Biotest AG, Dreieich, } \\
\text { Germany }\end{array}$ \\
\hline Approval no. & PEI.D.01488.01.1 & PEI.D.00863.01.1 & PEI.D.00235.01.1 & PEI.D.01269.01.1 \\
\hline Storage temperature, ${ }^{\circ} \mathrm{C}$ & $5 \pm 3$ & $\leq 25$ & $5 \pm 3$ & $\leq 25$ \\
\hline $\mathrm{MoAb}$ & $\begin{array}{l}\text { anti-A: Birma-1 } \\
\text { anti-B: LB-2 }\end{array}$ & $\begin{array}{l}\text { anti-A: Birma-1 } \\
\text { anti-B: LB-2 } \\
\text { anti-D: MS-201 }\end{array}$ & $\begin{array}{l}\text { anti-A: Birma-1 } \\
\text { anti-B: LB-2 }\end{array}$ & $\begin{array}{l}\text { anti-A: A003 } \\
\text { anti-B: B005 } \\
\text { anti-D: BS } 226\end{array}$ \\
\hline Tests per card & 2 & 1 & 4 & 2 \\
\hline Expiry date & on each card & on each wrapping & on each card & on each card \\
\hline Short instructions & on the card's back & on each wrapping & on 1 per 20 cards & on each wrapping \\
\hline Costs per card, EUR & no data available & 0.78 & 3.76 & 2.00 \\
\hline
\end{tabular}

$\mathrm{MoAb}=$ monoclonal antibody 
Table 2. Testing criteria of $\mathrm{ABO}$ bedside test cards $(1=$ very good $-6=$ very bad/ insufficient) ${ }^{\mathrm{a}}$

\begin{tabular}{lllll}
\hline Parameter & Card no. 1 & Card no. 2 & Card no. 3 & Card no. 4 \\
\hline Clear agglutination & $2(1-2)^{2}$ & $2(1-3)^{1,3,4}$ & $2(1-2)^{2}$ & $1(1-2)^{2}$ \\
Self explanatory & $2(1-3)$ & $2(1-3)$ & $2(1-3)$ & $2(1-2)$ \\
Labelling & $2(1-3)^{2,4}$ & $1(1-2)^{1,3}$ & $2(1-3)^{2,4}$ & $1(1-2)^{1,3}$ \\
Handling & $2(1-3)^{2,4}$ & $2(1-2)^{1,3}$ & $2(2-3)^{2,4}$ & $2(1-2)^{1,3}$ \\
Test system & $3(1-4)^{2,4}$ & $2(1-2)^{1,3}$ & $3(1-4)^{2,4}$ & $2(1-3)^{1,3}$ \\
User safety & $3(2-5)^{2,4}$ & $2(2-3)^{1,3}$ & $3(2-5)^{2,4}$ & $2(2-3)^{1,3}$ \\
\hline
\end{tabular}

${ }^{a}$ Values shown as median (25-75\% percentiles).

${ }^{1} \mathrm{p}<0.05$ (after Bonferroni correction) vs. card no. 1 .

${ }^{2} \mathrm{p}<0.05$ (after Bonferroni correction) vs. card no. 2

${ }^{3} \mathrm{p}<0.05$ (after Bonferroni correction) vs. card no. 3 .

${ }^{4} \mathrm{p}<0.05$ (after Bonferroni correction) vs. card no. 4 .

\section{Statistical Analysis}

Results are presented as mean \pm standard deviation if not otherwise stated. Statistical comparisons were made with the Kruskal-Wallis test using commercially available software (SPSS 11.0 for Windows, SPSS Software $\mathrm{GmbH}$, Munich, Germany). In case of significant differences, paired comparisons were made with the Student's t-test on paired variables after the significance level had been adjusted according to Bonferroni, relating a significance level of $5 \%$ to a $\mathrm{p}$ value $<0.008$ for six comparisons.

\section{Results}

All evaluation sheets were completed and returned. The ABO blood group was matched correctly by all four test systems. Except for handling, test system and user safety, all mean values were 1 (very good) or 2 (good) (table 2). Regarding quality of agglutination, cards no. 1 , no. 3 , and no. 4 received significantly better marks than card no. $2(\mathrm{p}<0.001)$. Analyzing card self explanation, no remarkable differences were noted among the four systems, except for a slight superiority of card no. 4 over no. 3 ( $p=0.038)$. Results obtained for card handling and labelling depended markedly on antibody reagent design: cards with dried antibodies (type I: cards no. 2, no. 4) reached significantly ( $\mathrm{p} \leq 0.003)$ better grades than those with covered liquid antibodies (type II: cards no. 1, no. 3) while differences within the respective card types were negligible ( $p \geq 0.218$ ). These results were reflected by evaluation of the test system itself and putative user safety with significant prominence of type I over type II $(p \leq 0.001)$ and similar values within the two card types $(p \geq 0.203)$.

\section{Discussion}

ABO incompatibility still represents one of the most threatening risks in transfusion medicine [7]. It is most often the result of human error [9] associated with a failure in organization [13]. Bedside testing performed immediately prior to transfusion can prevent this complication [4] and is therefore required by law in many countries. The critical issue in bedside testing for $\mathrm{ABO}$ compatibility is the accuracy of the test and its interpretation, depending markedly on correct use of the device $[15,16]$. As could be shown recently, high rates of erroneous transfusion decisions were due to defective techniques and poor user performance $[14,16]$. Some reports have been published to introduce new bedside test cards [17-19, 23], but only a few studies compared different card systems [6, 19]. So far, no publications focused on differences in card design, which could influence clearness of agglutination, handling, labelling, self-explanation and putative user safety, being of utmost importance for integration into clinical routine as well as correct test performance and interpretation. The ABO compatibility test is a laboratory test, and physicians or nurses are clearly not laboratory technicians. Thus, it is essential that users not involved in laboratory transfusion medicine performed the assessment of the test cards. We therefore recruited 100 medical students in the medical training status. Lack of transfusion experience was considered important as experience with a given test system/product may provoke a bias towards the known type. Furthermore, the risk of erroneous detection of agglutination is reported to decrease with increasing transfusion experience $[16,20,21,24]$ although inexperienced users must also be sure of their test results.

Overall, all cards received good marks and matched the given ABO blood group correctly. Therefore, statistically significant prominence observed for cards no. 1, no. 3, and no. 4 over card no. 2 concerning clearness of agglutination and for card type I (dried antibodies) concerning putative user safety relative to systems with film-covered liquid reagents (type II) must not automatically be of clinical relevance. However, especially an unambiguous and clear agglutination, best rated for card no. 4, is crucial for correct test interpretation [19, 20]. All features that facilitate the procedure and improve the detection of agglutination may reduce the risk of error [16], particularly in inexperienced investigators. Therefore, the inferiority of card no. 2 seems remarkable, especially when compared to card no. 4 , representing the same type with dried antibodies. Dilution with saline solution is known to simplify test interpretation and was described on the working instruction sheets, but 
lacked on the short instructions of card no. 2. This may probably explain the inferior agglutination marks of card no. 2 when students used the short instructions only. The inferiority of test systems with liquid antibodies concerning handling and putative user safety may probably be due to the necessity of an injection needle for these systems. Fear of an injury with a potentially contaminated needle might be greater than fear of blood-skin contact. Also labelling of card type I was rated significantly better compared to card type II, probably due to more distinct text fields (recipient's name, etc.) to be filled out. Even in the absence of working instructions, self-explanation was rated the same for all cards. Similarity between test systems appears to cover up application uncertainties.

In conclusion, all cards tested showed good results. Therefore, all four bedside cards can be recommended for clinical routine. Nevertheless, our study revealed significant differences regarding clear test interpretation and user safety. Systems with dried antibodies were regarded safer than systems with antibodies in liquid form. Only one card (no. 4) combined both good agglutination and user safety. Mathematically, the best results were obtained for card no. 4 , followed by cards no. 2, no. 1, and no. 3. Correct test interpretation also by users with little transfusion experience depends on correct use of the device which is facilitated by an easy and convenient test design, and the results of our study may help to lower the risk of misinterpretation. Last but not least, the efforts to prevent incidents of ABO mismatches should not be concentrated solely to the bedside compatibility test but also should reinforce a positive culture of error all along the transfusion process. An increase in transfusion safety may require the introduction of further systems [14], e.g. a tag on blood bags reminding staff to check a patient's wristband [25].

\section{Research Support}

Research material (bedside test cards) was in part supplied by all of the included companies (Biotest AG, Dreieich, Germany; Eldoncard A/S, Gentofte, Denmark; Medtro GmbH, Leimen-Gau, Germany; Organon Teknika, Eppelheim, Germany).

\section{References}

1 Linden JV, Wagner K, Voytovich AE, Sheehan J. Transfusion errors in New York State: an analysis of 10 years' experience. Transfusion 2000;40:12071213.

2 Müller Eckhard C, Kiefel V: Transfusionsmedizin, 3. Aufl. Heidelberg, Springer, 2003, p 330.

3 Wissenschaftlicher Beirat der Bundesärztekammer und des Paul-Ehrlich-Institutes: Richtlinien zur Gewinnung von Blut und Blutbestandteilen und zur Anwendung von Blutprodukten (Hämotherapie). Köln, Deutscher Ärzte-Verlag, 2005.

4 Bundesärztekammer: Leitlinien zur Therapie mit Blutkomponenten und Plasmaderivaten, 2. Aufl. Köln, Deutscher Ärzteverlag, 2003.

5 Le Pennec PY, Rouger P: Technical methods for the ultimate verification at the patient's bedside. Rev Fr Transfus Hemibiol 1991;34:167-171.

6 Noizat-Pirenne F, Le Pennec PY, Lascaux JM, Fraval D, Zaoui F, Rouger P: La verification ultime au lit du malade: resultats d'une enquete nationale sur les reactifs et dispositifs utilises en France. Transfus Clin Biol 1998;5:392-396.

7 Perrotta PL, Snyder EL: Non-infectious complications of transfusion therapy. Blood Rev 2001;15: 69-83.

8 Ibojie J, Urbaniak SJ: Comparing near misses with actual mistransfusion events: a more accurate reflection of transfusion errors. Br J Haematol 2000; 108:458-460.

9 Krombach J, Kampe S, Gathof BS, Diefenbach C, Kasper SM: Human error. The persisting risk of blood transfusion. A report of life cases. Anesth Analg 2002:94:154-156.
10 Shulman IA, Downes KA, Sazama K, Maffei LM: Pretransfusion compatibility testing for red blood cell administration. Curr Opin Hematol 2001;8:397404.

11 Linden JV: Errors in transfusion medicine. Scope of the problem. Arch Pathol Lab Med 1999;123:563565.

12 Linden JV, Paul B, Dressler KP: A report of 104 transfusion errors in New York State. Transfusion 1992:32:601-606.

13 Rouger P, Le Pennec PY, Noizat-Pirenne F: Immunologic risk analysis of blood transfusion: 1991-98 (in France). Transfus Clin Biol 2000;7:9-14.

14 Ahrens N, Pruss A, Kiesewetter H, Salama A: Failure of bedside $\mathrm{ABO}$ testing is still the moist common cause of incorrect blood transfusion in the barcode era. Transfus Apher Sci 2005;33:25-29.

15 Caspari G, Alpen U, Greinacher A: The risk of transfusion to the wrong patient in Germany. Transfusion 2002;42:1238-1239.

16 Migeot V, Ingrand I, Salmi LR, Ingrand P: Reliability of bedside $\mathrm{ABO}$ testing before transfusion. Transfusion 2002;42:1348-1355.

17 Geisen HP, Baumgartner E: ABO crossmatching the bedside test - with a new system. Anaesth Intensivther Notfallmed 1980;15:166-168.

18 Meinshausen E, Wendt M: Introduction of a new card for the 'bedside test'. Anaesthesist 1989;38: 555-557.

19 Braun-Oberdieck B: Erfahrungen mit 'BedsideCards' in der Immunhämatologie. mta Fachzeitschrift der Technischen Assistenten in der Medizin 1988;1.
20 Dujardin PP, Salmi LR, Ingrand P: Errors in interpreting the pretransfusion bedside compatibility test: an experimental study. Vox Sang 2000;78:37-43.

21 Ingrand P, Surer-Pierres N, Houssay D, Salmi LR: Reliability of the pretransfusion bedside compatibility test: association with transfusion practice and training. Transfusion 1998:38:1030-1036.

22 Uthemann H, Weber M: Securing the ABO identity by serafol before blood transfusions. Anaesthesist 1982;31:204-205.

23 Rachel JM, Plapp FV: Bedside blood grouping. Med Lab Sci 1990;47:330-336.

24 Saillour- Glenisson F, Tricaut S, MathoulinPellissier S, Bouchon B, Galperine I, Fialon P, Salmi LR: Factors associated with nurses' poor knowledge and practice of transfusion safety procedures in Aquitaine, France. Int J Qual Health Care 2002;14:25-32

25 Murphy MF, Casbard AC, Ballard S, Shulman IA, Heddle N, Aubuchon JP, Wendel S, Thomson A, Hervig T, Downes K, Carey PM, Dzik WH: Prevention of bedside errors in transfusion medicine (PROBE-TM) study: a cluster-randomized, matchedpaired clinical areas trial of a simple intervention to reduce errors in the pretransfusion bedside check. Transfusion 2007;47:771-780. 